ARTICLE

https://doi.org/10.1038/s41467-019-08623-1

OPEN

\title{
Specialized rainforest hunting by Homo sapiens $\sim 45,000$ years ago
}

\author{
Oshan Wedage ${ }^{1,2}$, Noel Amano (1) 1, Michelle C. Langley ${ }^{3}$, Katerina Douka1,4, James Blinkhorn ${ }^{1,5}$, \\ Alison Crowther ${ }^{6}$, Siran Deraniyagala ${ }^{7}$, Nikos Kourampas ${ }^{8,9}$, lan Simpson (1) ${ }^{8}$, Nimal Perera ${ }^{7}$, Andrea Picin ${ }^{1}$, \\ Nicole Boivin ${ }^{1}$, Michael Petraglia (i] ${ }^{1,10}$ \& Patrick Roberts (i) ${ }^{1}$
}

Defining the distinctive capacities of Homo sapiens relative to other hominins is a major focus for human evolutionary studies. It has been argued that the procurement of small, difficult-tocatch, agile prey is a hallmark of complex behavior unique to our species; however, most research in this regard has been limited to the last 20,000 years in Europe and the Levant. Here, we present detailed faunal assemblage and taphonomic data from Fa-Hien Lena Cave in Sri Lanka that demonstrates specialized, sophisticated hunting of semi-arboreal and arboreal monkey and squirrel populations from ca. 45,000 years ago, in a tropical rainforest environment. Facilitated by complex osseous and microlithic technologies, we argue these data highlight that the early capture of small, elusive mammals was part of the plastic behavior of Homo sapiens that allowed it to rapidly colonize a series of extreme environments that were apparently untouched by its hominin relatives.

\footnotetext{
${ }^{1}$ Department of Archaeology, Max Planck Institute for the Science of Human History, 07745 Jena, Germany. ${ }^{2}$ Department of History and Archaeology, University of Sri Jayewardenepura, Gangodawila, Nugegoda, Colombo 10250, Sri Lanka. ${ }^{3}$ Australian Research Centre for Human Evolution, Environmental Futures Research Institute, Griffith University, Nathan, Brisbane, QLD 4111, Australia. ${ }^{4}$ Research Laboratory for Archaeology and the History of Art, University of Oxford, Oxford OX1 3QY, UK. ${ }^{5}$ Department of Geography, Royal Holloway, University of London, Egham, Surrey TW20 OEX, UK. ${ }^{6}$ Department of Archaeology, University of Queensland, Brisbane, QLD 4072, Australia. ${ }^{7}$ Department of Archaeology, Government of Sri Lanka, Colombo 00700 , Sri Lanka. ${ }^{8}$ Biological \& Environmental Science, University of Stirling, Stirling FK9 4LA, UK. ${ }^{9}$ Center for Open Learning, University of Edinburgh, Edinburgh EH8 8AQ, UK. ${ }^{10}$ Human Origins Program, National Museum of Natural History, Smithsonian Institution, Washington, DC 20013-7012, USA. These authors contributed equally: Oshan Wedage, Noel Amano. Correspondence and requests for materials should be addressed to O.W. (email: wedage@shh.mpg.de) or to N.A. (email: amano@shh.mpg.de) or to M.P. (email: petraglia@shh.mpg.de) or to P.R. (email: roberts@shh.mpg.de)
} 
T here is growing evidence that Homo sapiens had a unique capacity to adapt to a diversity of extreme environments, both within and beyond Africa, when compared with other members of the genus $\mathrm{Homo}^{1}$. Nevertheless, studies of migrations of our species into Europe, the Middle East, and Asia have often focused on its increased efficiency in hunting, butchering, and consuming medium-to-large game in open "savanna" settings $s^{2,3}$. Alternatively, coastal settings have been highlighted as providing homogeneous, protein-rich resources that stimulated human evolution as well as migration beyond Africa from the Late Pleistocene $e^{4,5}$. Focus on these environments has meant that small mammals have been neglected in discussions of the human colonization of new environments, despite the fact that a specialization in their procurement is often considered a feature of technological and behavioral "complexity" or "modernity" unique to our species ${ }^{6,7}$. Concentration on Europe and West Asia in this regard has linked increased usage and capture of agile, but abundant, small mammals to human population growth or climatically driven crises associated with the end of the last glacial period $^{6}$. Nevertheless, the onset and behavioral context of small mammal hunting in other parts of the world, and beyond temperate environments, has remained poorly studied.

From the Late Pleistocene onwards, our species inhabited a number of diverse environments as it dispersed beyond Africa. One of these environments, tropical rainforests, has been considered a barrier to human dispersal 8 ,9. This was mainly due to the fact that mammalian megafauna $\left(>44 \mathrm{~kg}^{10}\right)$, thought to have been attractive to Late Pleistocene humans, and even driven to extinction as a result of our species' expansion ${ }^{11,12}$, are lacking in these settings ${ }^{8}$. Nevertheless, in Sri Lanka, Southeast Asia, and Melanesia, as well as other parts of the world, the earliest evidence for human occupation is often associated with rainforest environments ${ }^{13-16}$. In Sri Lanka, stable isotope evidence has demonstrated that humans relied on rainforest resources for over 30,000 years ${ }^{17}$, perhaps aided by the complex microlith and bone toolkits found at Late Pleistocene and early Holocene sites in the region ${ }^{15,16,18}$. However, owing to a lack of detailed faunal analyses, it has remained unknown which foodstuffs sustained human populations during this time, as well as the hunting strategies employed to obtain them.

We apply new chronometric, taphonomic, archaeozoological, and artifactual analyses to the earliest dated archeological site in Sri Lanka, Fa-Hien Lena (Fig. 1), previously dated to 38,000 years $\mathrm{ago}^{18-20}$. Fa-Hien Lena documents the earliest fossil appearance of H. sapiens in Sri Lanka, and indeed South Asia, alongside small, quartz microlith technology, and a variety of pointed bone technologies ${ }^{18-20}$. Rainforest mammals, reptiles, molluscs, and plant remains have been identified at the site ${ }^{18,20,21}$. However, human exploitation of specific resources has yet to be directly demonstrated owing to a lack of systematic taphonomic study. Similarly, the early, enigmatic microlith and bone technologies discovered here and elsewhere in South Asia have undergone limited analysis, and their use and adaptive function have remained obscure ${ }^{19,20,22}$. The results of our new multidisciplinary analyses document specialized, sophisticated hunting of semiarboreal and arboreal prey taxa from ca. 45,000 years ago, in the tropical rainforest environments of Sri Lanka.
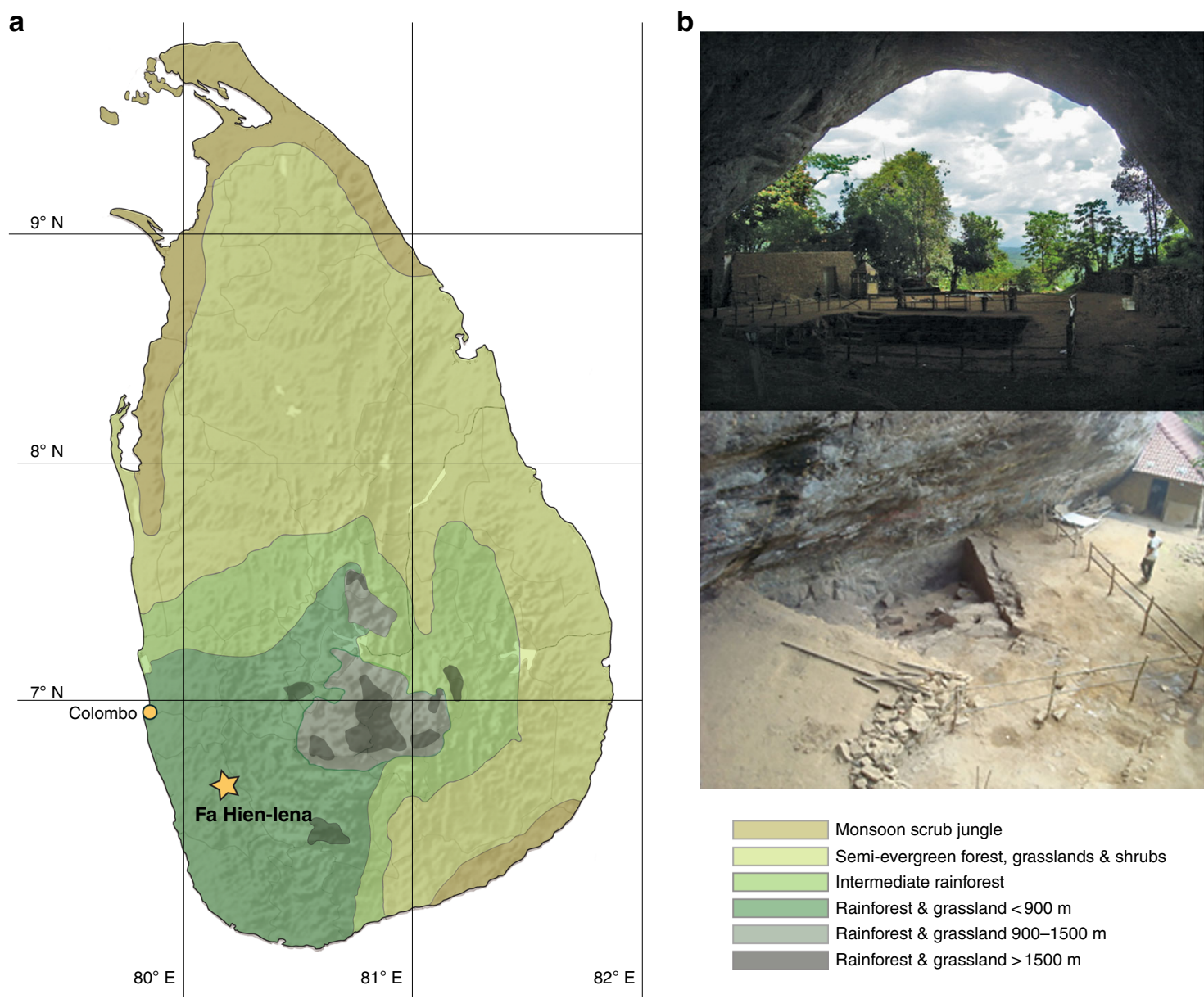

Fig. 1 Location of Fa-Hien Lena. a Map of Sri Lanka showing the location of Fa-Hien Lena and the country's vegetation zones ${ }^{44,45}$. $\mathbf{b}$ Excavation in Fa-Hien Lena 


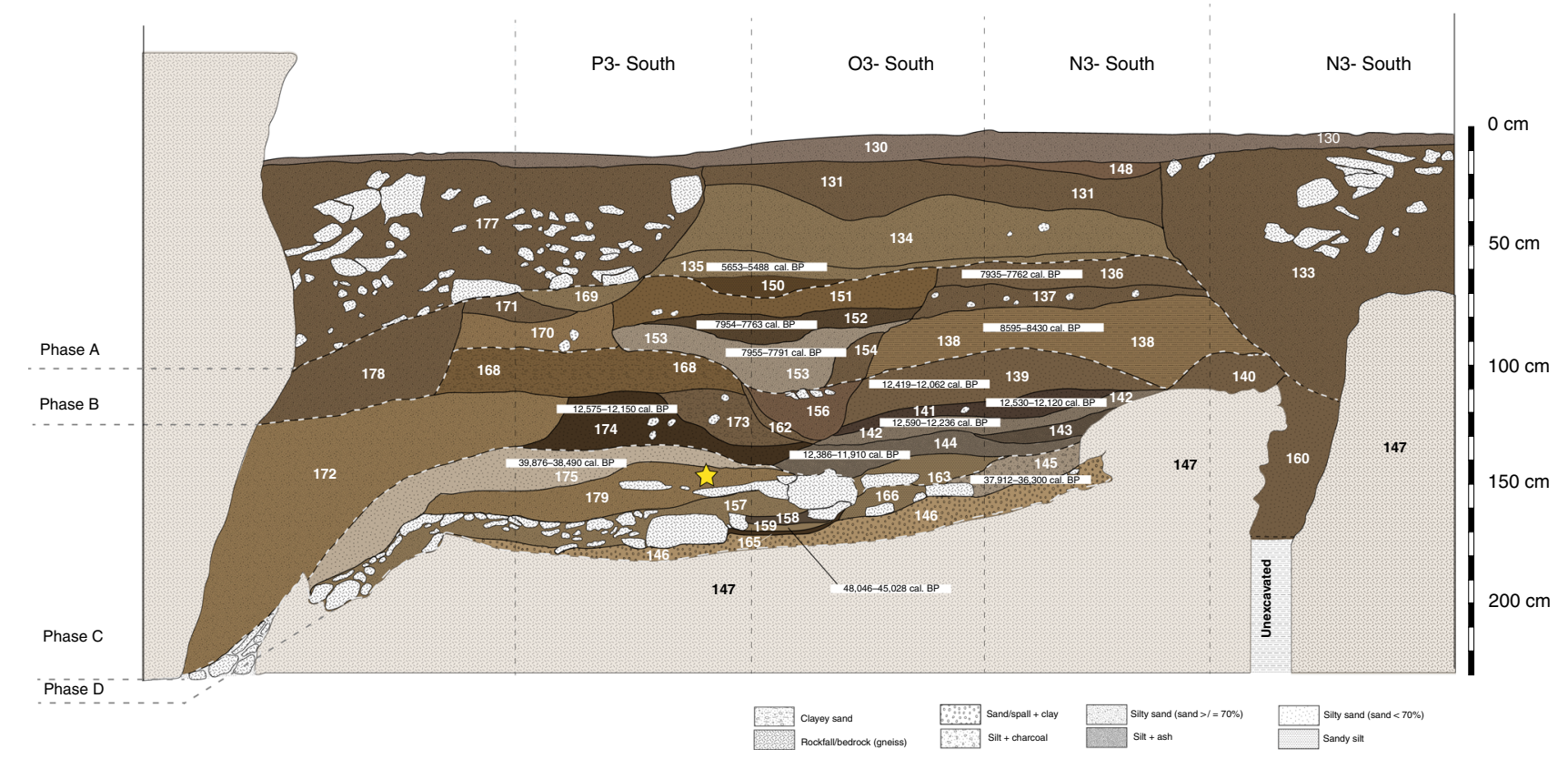

Fig. 2 Stratigraphy of Fa-Hien Lena. South wall, end of the 2010 excavation. The star indicates the approximate stratigraphic location ${ }^{19}$ of the fossils described by Kennedy 23

\section{Results}

Stratigraphy and chronology. We divide the dates available for the site into four distinct phases based on our new, and previous, excavations ${ }^{19,23}$. The phases correspond to concentrations of charcoal, faunal remains, and artifacts, including osseous tools, shell beads, and quartz flakes (Supplementary Figure 1), and represent the major periods of human occupation of the cave. Phase D contains evidence for Late Pleistocene occupation of the cave from c. 48,000 to $34,000 \mathrm{cal}$. BP and probably included several episodes of occupation, each of which may have been relatively short-lived. Phase $\mathrm{C}$ spans the Terminal Pleistocene occupation from c. 13,000-12,000 cal. BP, while Phases B and A span the Early $(8700$ to $8000 \mathrm{cal}$. BP) and Middle (6000 to 4000 cal. BP) Holocene, respectively. One radiocarbon date falls outside these phases $(29,120-27,870 \mathrm{cal}$. BP) and may represent a short-lived episode of human presence in the cave.

These phases also align with major lithostratigraphic changes (Fig. 2). The fill of Fa-Hien Lena consists of $c .170 \mathrm{~cm}$ of detrital sediment deposited above heavily weathered and karstified gneiss blocks. Phase D consists of pebbly loams and clayey and sandy silt deposits with laminated ash representing intermittent/episodic human occupation and colluvial inwash. The deposits yielded a variety of evidence for human activity, including heavily burned/ calcined faunal remains, shell beads, bone tools, and ocher fragments, in addition to micromorphological analyses of sediments evidencing in situ burning (Supplementary Note 1). A roof fall episode appears to have contributed to the exceptional preservation of these deposits by sealing large parts of Phase D from later disturbance. Phase $\mathrm{C}$, which contains the heaviest concentration of artifacts and human occupation debris in the stratigraphy, comprises of a rapidly deposited, heterogeneous mixture of dark colored, organic-rich sandy silty loams. Phases B and $\mathrm{A}$ are made up of light colored sandy silts and ash accumulations. For further detailed description, see Supplementary Note 1, Supplementary Tables 1-4, and Supplementary Figures 1-4.

Previous excavation in Fa-Hien-lena produced the oldest human fossils so far in Sri Lanka. Remains of a 5.5-6.5 years old child, mixed with remains of at least two infants as well as a young adult female, were dated based on associated charcoal to $30,600+360 \mathrm{BP}^{23}$. These remains were found in layer 4 at the rear of the cave during the 1986 excavations ${ }^{19}$ (approximately represented by context 179 during our 2010 excavations) (Fig. 2). Overall, our new data confirm Fa-Hien Lena as the oldest site with $H$. sapiens fossils in Sri Lanka, and wider South Asia ${ }^{19,20}$. They also indicate that Fa-Hien Lena now represents one of the earliest appearances of microlith toolkits and bone tool technocomplexes outside of Africa.

Zooarchaeology and taphonomy. Our detailed taphonomic and archaeozoological study of faunal remains at Fa-Hien Lena examined the adaptive context of the first humans on the island. We analyzed a total of 14,485 bone and tooth fragments from the site, $52.6 \%$ of which were identified to taxon (number of identified specimens, NISP $=7622$ ). The full dataset can be found in Supplementary Note 2 (see also Supplementary Figures 5-16; Supplementary Tables 5-42). Small mammals (i.e., weighing less than $25 \mathrm{~kg}$ ) overwhelmingly dominate the faunal assemblage starting from the earliest phase of occupation (c. 48,000-34,000 cal. BP). These animals, including carnivores such as the civet cat, account for more than $90 \%$ of the NISP, suggesting deliberate hunting from the Late Pleistocene until the Mid-Holocene (Fig. 3) (Supplementary Note 2). Reptiles, including pythons, colubrid snakes, and water monitors, and fish (mostly catfish and carp) are also present in all phases of site occupation. Several of the specimens identified could represent fauna from natural accumulations (e.g., murids and amphibians accumulated by raptors, $1.9 \%$ of the total NISP, see Supplementary Note 2). Other specimens, including birds such as swifts and swallows and squamates such as snakes and varanids, could represent the cave's natural faunal communities. However, the high percentage of burning ( $>50 \%$ in Phase D) in squamate remains suggests that they were most likely utilized by the people that occupied the site (Supplementary Note 2).

There is no significant difference in the distribution of mammals based on body size from the Late Pleistocene to the Mid-Holocene (Supplementary Note 2). Large ungulates, including cervid, suid, and bovid are present throughout the 
a

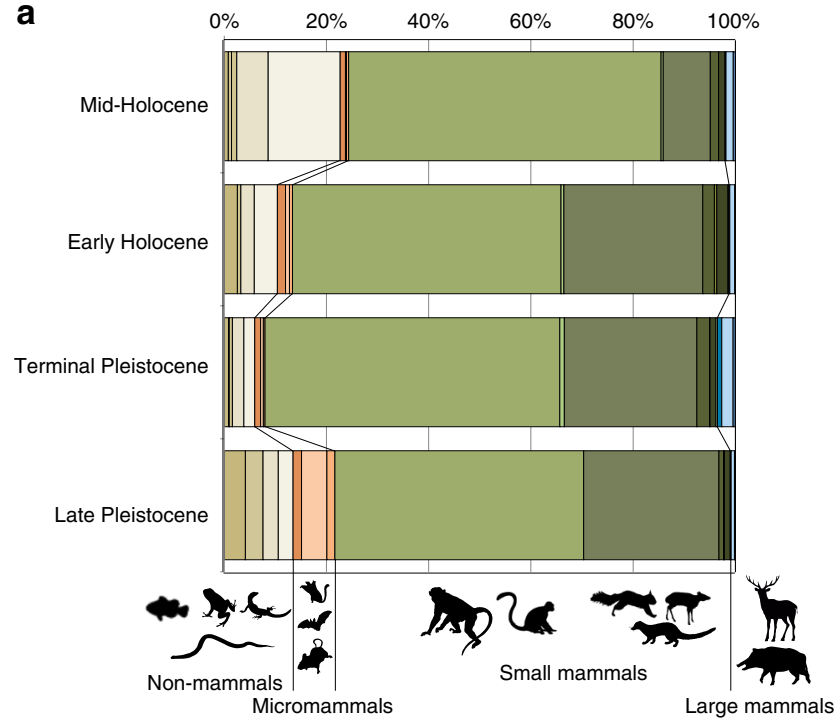

b

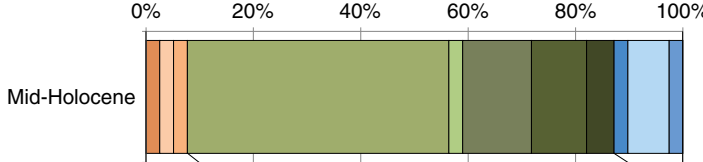

Early Holocene
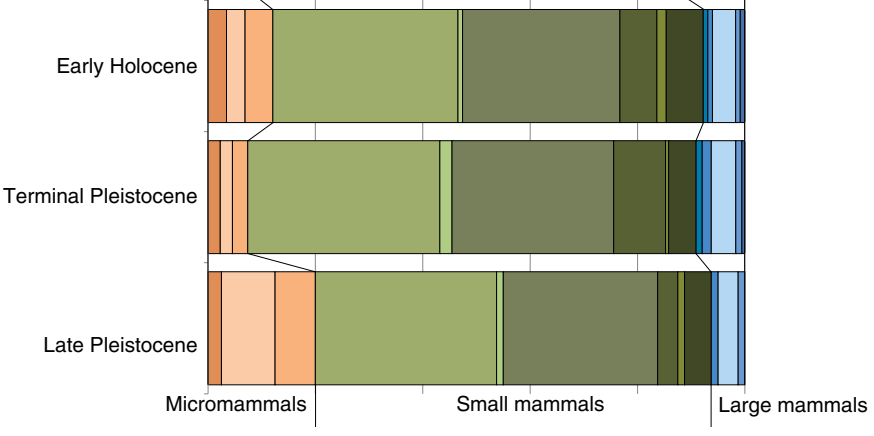

$\square$ Petaurista + Petinomys $\square$ Ratufa

$\square$ Muridae + Soricidae $\square$ Viverridae + Mustelidae + Herpestidae $\square$ Cervidae

$\square$ Microchiroptera $\square$ Pteropodidae $\quad \square$ Bovidae

$\square$ Cercopithecidae $\square$ Tragulidae $\square$ Elephantidae + Rhinocerotidae

$\square$ Hystricidae + Leporidae $\square$ Canidae

Fig. 3 Animal taxa identified in Fa-Hien Lena. Distribution of animal taxa identified in the different occupational phases of Fa-Hien Lena based on the number of identified specimens (NISP, a) and the minimum number of individuals (MNI, b). (Brown: non-mammals; orange: micromammals; green: small mammals; blue: large mammals)

stratigraphy but at very low frequencies $(<4 \%)$. Monkeys and tree squirrels overwhelmingly dominate the faunal assemblage in all phases of site occupation, accounting for more than $70 \%$ of the identified remains (or $82.4 \%$ of the total NISP discounting fauna most likely accumulated by non-human cave dwelling species). They represent $84.7 \%$ and $76.3 \%$ of the total number of identified specimens in the Terminal and Late Pleistocene layers, respectively $(72.3 \%$ and $66.7 \%$ of the minimum number of individuals, MNI). Of the taxa identified in the Late Pleistocene layers, $48.7 \%$ are cercopithecoid monkeys. Deliberate targeting of monkeys continued until the Mid-Holocene, where cercopithecoids represent $61.1 \%$ of the number of identified bone and tooth fragments. Three cercopithecoid species are currently present in Sri Lanka: the cercopithecine Macaca sinica (toque macaque), the colobine monkeys Trachypithecus vetulus (purple-faced langur), and Semnopithecus priam (tufted gray langur). These species occur sympatrically and all were identified in the site. Macaques slightly outnumber the leaf monkeys in the faunal assemblage (Supplementary Note 2).

Mortality profiles based on dental eruption and wear suggest that prime-aged adults were deliberately targeted. This, and the fact that the identified monkey species are today mostly arboreal and rarely venture to the ground ${ }^{24,25}$, suggests that they were most likely captured by targeted hunting. Trapping usually results in mortality profiles similar to those found in natural populations ${ }^{26-28}$. The presence of bone points and microliths from the outset of site occupation hints at the possible use of projectile technology to hunt arboreal prey (see below, and Supplementary Note 3, Supplementary Figures 17-19, and Supplementary Tables 43 and 44). Modern Southeast Asian hunter-gatherer communities still rely on the use of projectile weapons, including darts and blowpipes, to target arboreal and semi-arboreal $\operatorname{taxa}^{29-31}$. The archaeological bone points are consistent in size and breakage patterns with such uses. Regardless of method of capture, entire monkey carcasses were brought and processed in the site as revealed by the pattern of skeletal part abundance (Supplementary Note 2).

Bone fragments with anthropic modification, ranging from burning to butchery marks, were recovered in all phases of site occupation. Butchery marks were recorded on a total of 92 bone fragments $(0.64 \%)$, the majority of which were from small mammals (92.2\%) (Supplementary Note 2). The Late Pleistocene layers yielded a total of nine ( $0.7 \%$ of NISP) bone fragments with clear evidence for butchery, including squirrel, otter, and civet cat long bones from the oldest occupation deposit of the site (Fig. 4). The placement of the cutmarks, both in the shaft surface and the distal epiphyses, is suggestive of a carcass processing sequence that involved disarticulation and defleshing ${ }^{32}$. Burnt and calcined bone fragments represent $19.7 \%$ of the total specimens studied (23.9\% of the Late Pleistocene assemblage). A high proportion of the small mammal (17.1\%) remains identified at the site exhibit evidence for burning, including $16.1 \%$ of the monkey remains.

Bone tool industry. Primates and giant squirrels appear to have been targeted not just for subsistence, but also for technological production. A total of 36 bone specimens with surface modifications consistent with systematic tool manufacture were recorded in the Late Pleistocene layers (Phase D) of the site $(1.3 \%$ of the NISP). These consist of 10 fragments of finished implements, including proximally hafted unipoints, mesially hafted bipoints, and small geometric bipoints. The rest are fragments that represent either waste pieces or tool blanks. These specimens are characterized by the presence of heavy surface and/or edge polish and striations or grinding marks. In situ tool production accounts for the high level of fragmentation of cercopithecid bones in all levels of site occupation, but most notably in the Late Pleistocene layers (Supplementary Note 2).

The osseous tools from the Late Pleistocene layers of the site appear to have been manufactured exclusively from cercopithecid long bone fragments, save for one worked macaque canine recorded from the earliest phase of site occupation (context 253) (Fig. 4). Tools and artifacts made from large ungulate bone, teeth, and antler only start to appear during the Terminal Pleistocene. Most of the bone points examined exhibited evidence for damage consistent with high velocity impact (four out of the five points recorded in Phase D, e.g., Fig. 4$)^{33}$, which, in addition to what appears to be deliberate targeting of prime age adults, further 

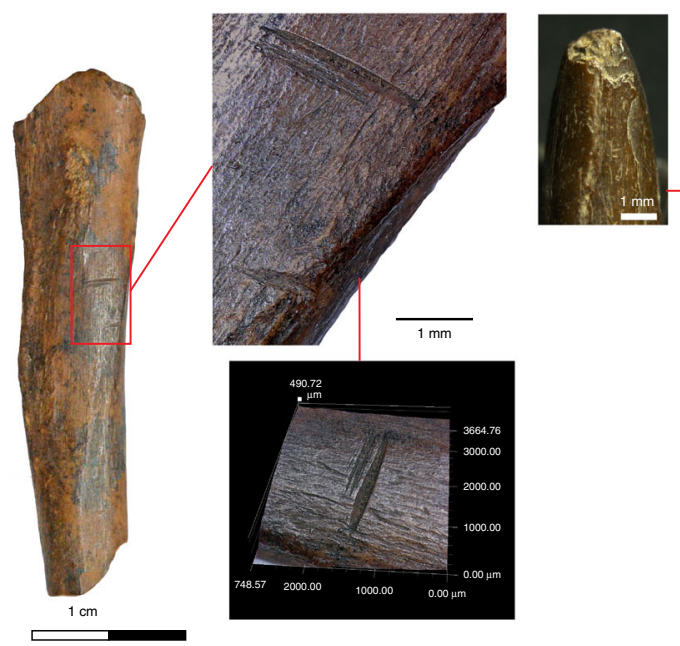

b

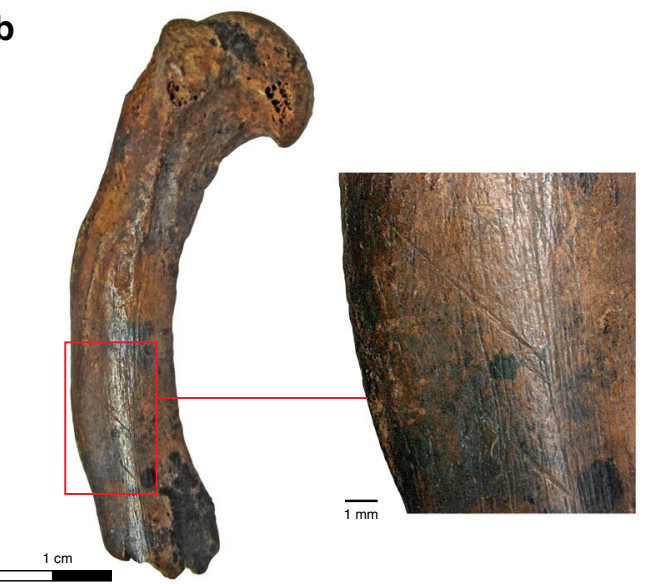

C
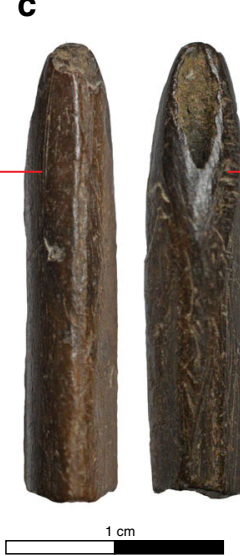

$\mathbf{9}$
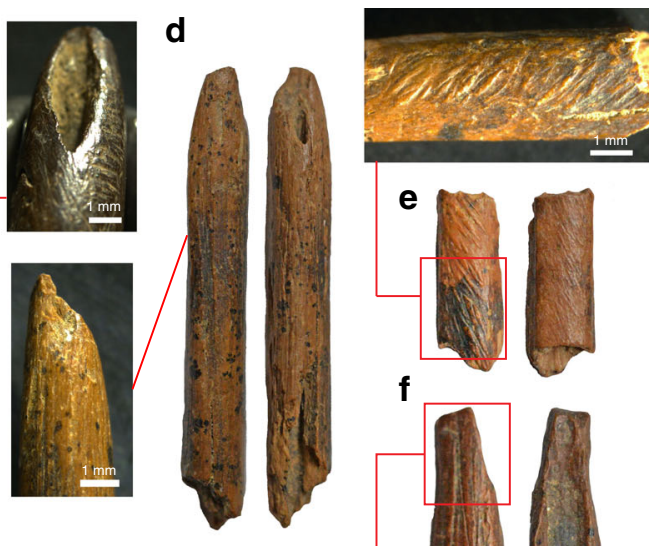

e

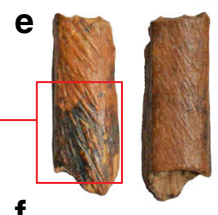

f

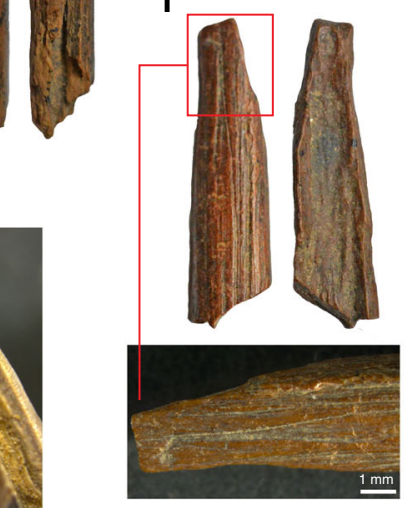

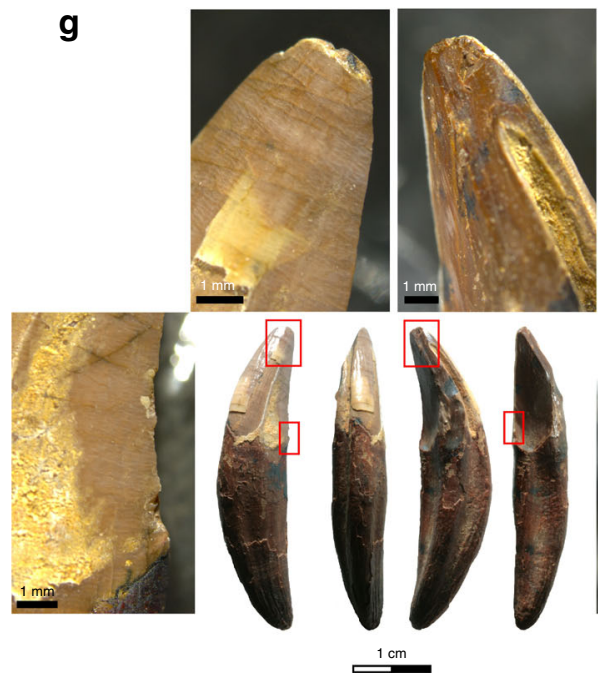

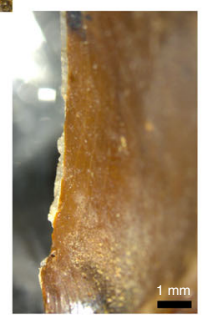

Fig. 4 Specimens with anthropic modifications from the Late Pleistocene layers of Fa-Hien Lena. Bone fragments with evidence for butchery and osseous tools and artifacts from the earliest phase of occupation at Fa-Hien Lena. a Cutmarks on a grizzled giant squirrel (Ratufa) tibia. b Cutmarks on an otter (Lutra) humerus. c, d Cercopithecid monkey fibula points with evidence for shaping (ground) before high-pressure tip use. e Monkey distal fibula shaft fragment with grinding marks. $\mathbf{f}$ Worked monkey femur shaft fragment. $\mathbf{g}$ Worked macaque canine showing damage from use in cutting (on sides) and pressure/piercing on tip

suggests that projectile hunting, rather than trapping, was utilized in the exploitation of small semi-arboreal and arboreal game.

\section{Discussion}

The consistently high percentage of arboreal small mammal taxa in all phases of occupation in Fa-Hien Lena is unheard of even among modern ethnographic groups hunting in tropical rainforest environments ${ }^{20,34}$, with perhaps one exception ${ }^{35}$. Even with access to rifle technologies and wire cord and snare traps, modern foragers never show such a bias ${ }^{34}$. Late Pleistocene hunting of arboreal primates has also been demonstrated at the Niah Caves, Borneo from 50,000 to 35,0000 years BP. However, here, in contrast to Fa-Hien Lena, humans seemingly primarily relied on large ungulates as their main source of protein ${ }^{28}$. This, alongside associated evidence from what is, to our knowledge, one of the earliest bone tool assemblages in South and Southeast Asia (contemporaneous with the bone tools from Niah Caves dated between 50,000 and 35,000 years $\mathrm{BP}^{33}$ ), and also one of the earliest beyond Africa, implies highly tuned hunting abilities in tropical rainforest settings upon arrival in this part of the world. Moreover, despite targeting prime age adults, these human populations were able to exploit primate and giant squirrel taxa, often considered to be rainforest game types that are among the most vulnerable to overhunting ${ }^{36}$, from $\sim 45,000$ to 4,000 years ago. This suggests close knowledge of life cycles, territories, and sustainable hunting strategies ${ }^{37}$.

Discussions of Late Pleistocene dispersals of $H$. sapiens beyond Africa have tended to focus on human reliance on large, mammalian megafauna that are often linked to open grassland or mixed woodland and grassland environments ${ }^{8,11}$. Alternatively, scholars have focused on reliable coastal resources as providing adaptive corridors for a rapid dispersal around the Indian Ocean, through Southeast Asia, and into Australia ${ }^{4,5}$, and also into the Americas $^{38}$. Our current data, demonstrate instead that some of the earliest known H. sapiens in Sri Lanka, and indeed in the South Asian tropics, focused on the specialized hunting of small semi-arboreal and arboreal mammals in tropical rainforests. Traditionally, the use of such difficult-to-catch resources has been associated with a "broad spectrum" revolution in the face of growing populations and climate change. However, continued emphasis on prime age animals across over 40,000 years, rather than a broadening of capture strategy, implies no such stress in the tropical rainforests of Sri Lanka. Furthermore, while stable isotopic data from human and faunal tooth enamel in the Wet Zone of Sri Lanka highlights subtle environmental changes from the Late Pleistocene to the Holocene, the persistence of Wet Zone and Intermediate Zone rainforest, as well as human reliance on 
this forest ${ }^{17,39}$, suggests these environments did not reach carrying capacity.

As a consequence, the utilization of these energetically expensive resources developed in the absence of resource pressure, documents the behavioral and technological flexibility of $H$. sapiens. These complex subsistence strategies appear to be part of the adaptive ecological plasticity of our species that enabled it to inhabit diverse Late Pleistocene habitats across the world ${ }^{1}$. The primary niche of non- $H$. sapiens hominins within and beyond Africa appears to be diverse forest and grassland mosaics in the vicinity of rivers and lakes ${ }^{40,41}$. By contrast, following its evolution in Africa c. $300 \mathrm{ka}^{42}$, our species came to occupy higherelevation niches than its hominin predecessors, as well as deserts, palaeoarctic settings, and tropical rainforest habitats stretching across Asia, Melanesia, and North, Central, and South Americal. Moreover, it was even able to alter and manage environments, such as tropical forests, to meet its own subsistence and cultural needs through ever-intensifying niche-construction ${ }^{39,43}$. Detailed paleoecological and archeological analysis, such as that presented here, offers to yield more insights into the variety of cultural and subsistence strategies that facilitated the eventual colonization of all of the world's continents, and resilience to increasingly extreme Pleistocene climatic fluctuations, that left $H$. sapiens the last hominin standing on the face of the planet.

\section{Methods}

Chronology and thin section micromorphology. Fa-Hien Lena $\left(80^{\circ} 12^{\prime} 55^{\prime \prime} \mathrm{E}, 6^{\circ}\right.$ $38^{\prime} 55^{\prime \prime} \mathrm{N}$ ) is located in Sri Lanka's Wet Zone region, near the town of Bulathsinhala, some $75 \mathrm{~km}$ southeast of Colombo in a lowland evergreen and semievergreen rainforest environment ${ }^{44,45}$. The cave, on the slope of a gneiss cliff, has a c. $30 \mathrm{~m}$ by $20 \mathrm{~m}$ east-facing entrance, an interior that extends $c .10 \mathrm{~m}$ into the cliff, and two main chambers (termed shelters A and B). First recorded by S.U. Deraniyagala in 1968, Fa-Hien Lena was systematically excavated over several seasons from 1986 to 1988 by W.H. Wijeyapala, and from 2009 to 2012 by a team led by O. Wedage, S.U. Deraniyagala, and N. Perera. Shelter A, the larger of the cave's chambers, was excavated to a depth of over $6 \mathrm{~m}$. However, the shelter's archaeological deposits are disturbed by recent Buddhist constructions. Shelter B, on the other hand, produced a sequence of archaeological deposits spanning from what appears to be the earliest occupation of Sri Lanka by our species (previously dated to $38,000 \mathrm{cal}$. $\mathrm{BP}^{19,20}$ ) through to the Middle Holocene.

This paper presents the results of the analyses of materials from 2009 to 2012 excavations. We added to existing radiocarbon dates and present a revised stratigraphy for the site. Together with dates previously published ${ }^{19,23,46,47}$, which we calibrated using OxCal $4.3^{48}$, we present a total of 30 radiocarbon dates (Supplementary Tables 1-4) that are now available for Fa-Hien Lena, enabling detailed phasing for the site.

A set of undisturbed sediment samples were collected from the excavated profile in clear polyurethane boxes. Sample boxes were labeled, photographed, and plotted on the profile drawing before removal from the profile. Four of these samples, all from Phase D sediments, were selected for micromorphological analysis (Supplementary Figure 2), aiming to understand the depositional history and to access the taphonomic integrity of these earliest occupation deposits. Sample processing, at the Thin Section Micromorphology Laboratory, University of Stirling included air-drying and impregnation with polyester (polylite) resin (http://www. thin.stir.ac.uk/). c. $30-\mu \mathrm{m}$ thick, covered, large format thin sections $(7.5 \times 11 \mathrm{~cm})$ were manufactured from the hardened impregnated blocks (sample code $\mathrm{FH}$ ). Thin sections were observed with a polarizing microscope at magnifications of $\times 12.5$ to $\times 400$, using plain polarized (PPL), cross-polarised (XPL), and oblique incident light (OIL). The relative abundance of sediment components was estimated using standard semi-quantitative estimation charts ${ }^{49,50}$.

Zooarchaeology and taphonomy. We analyzed faunal remains recovered from the 2009 and 2012 excavations of Fa-Hien Lena. All bone fragments from sedimentary contexts with secure radiocarbon dates (including those from deposits sandwiched by dated layers) were included in the analysis. All specimens, including diaphyses and rib shafts, were sorted, counted, and measured (length, width, and thickness) using a digital caliper (Mitutoyo 500-463). Identified specimens were recorded in detail using codes for anatomic zones ${ }^{51}$ (e.g., Supplementary Figure 5) that allow the description of bone preservation/fragmentation patterns. Diagnostic dental and skeletal elements were identified to the highest possible taxonomic level using vertebrate comparative collections from the Laboratory of Comparative Anatomy of the Muséum national d'Histoire naturelle (MNHN) in Paris and photographs from the mammalian collections of the Field Museum of Natural History and American Museum of Natural History. Following von den Driesch ${ }^{52}$, individual dental specimens and specific anatomical features of diagnostic skeletal elements were measured to differentiate between closely related taxa. The naming of identified taxa follows the nomenclature for mammalian species of Wilson and Reeder $^{53}$. The taxa identified in the sites were assigned to size class based on live weight (modified from refs. ${ }^{54,55}$ ): (a) micromammals: $100 \mathrm{~g}$ to $1 \mathrm{~kg}$, (b) small mammals: $1 \mathrm{~kg}$ to $25 \mathrm{~kg}$, (c) large mammals class $1: 25 \mathrm{~kg}$ to $200 \mathrm{~kg}$, (d) large mammals class 2: $200 \mathrm{~kg}$ to $1000 \mathrm{~kg}$, and (e) large mammals class $3:>1000 \mathrm{~kg}$.

All fragments were examined for natural, animal, and anthropic modifications, including weathering 56,57 , abrasion ${ }^{58}$, burning, staining, and butchery marks ${ }^{32}$. Bone surface modifications were recorded/observed using an Olympus BX53 light microscope and a Keyence VHX-6000 digital microscope. Burnt bone fragments were identified based on color ${ }^{59-61}$. They were distinguished into different classes based on the degree of burning ${ }^{56}$ : (1) partially burnt, (2) charred (blackened), and (3) calcined (partial and complete calcination). Burnt bones were quantified by determining the percentage of the total bone fragments that is comprised of burnt specimens ${ }^{62,63}$.

The minimum number of element (MNE) and minimum number of individual (MNI) counts were calculated following a modification of Dobney and Rielly's ${ }^{51}$ zonation system. This system is based on the recording of morphologically distinct zones in a skeletal element. The MNE was taken as the total number of nonrepeatable zones (i.e., greater than $50 \%$ of the diagnostic zone present) for every skeletal element of a taxon. The highest MNE value, considering side and age (epiphyseal fusion and dental wear ${ }^{64}$ ), was used to estimate the MNI. The MNE counts were converted to minimum animal unit (MAU) values by taking into account the number of times the element occurs in the skeleton. The normed MAU values (\% MAU) were used to compare skeletal part representation in the different phases of cave occupation 65 .

The length and circumference of long bone fragments were also recorded in relation to complete specimens to measure the extent of bone fragmentation in the assemblage. Long bone fragments were assigned the following fragment circumference and length scores ${ }^{66,67}$ : (1) fragments with less than half of the circumference/length of the complete specimen, (2) fragments with more than half of the circumference/length of the complete specimen, and (3) fragments with the complete circumference/length of the complete specimen.

Artifact analysis. The technological study of the lithic assemblages of Fa-Hien Lena was carried out following the chaîne opératoire concept ${ }^{68,69}$, a methodological framework that defines the reconstruction of the various processes of flake production from the procurement of raw materials, through the phases of manufacture and utilization until the final discard. The chaîne opératoire concept provides systematic sequences of the flaking activities in which is possible to determine the temporal phase and the position of the artifact produced $^{70}$. The lithic material is composed of 5070 items (Supplementary Tables 43-44). The predominant raw material is quartz, which is abundantly available in the streams nearby.

Few chert blanks were also found and include: a siret flake fragment in context 131 (Phase A); two flakes and a fragment in context 136 (Phase B); a flake fragment in context 141; and one flake and one blade from context 248 (Phase C).

For the analysis of osseous artifacts, the materials were examined using a Zeiss Stemi 508 stereomicroscope fitted with an AxioCam 105 camera. Taphonomic and anthropogenic alterations were identified based on published works ${ }^{58,71-78}$ and mapped onto photographs taken with a Canon digital SLR camera.

Reporting summary. Further information on research design is available in the Nature Research Reporting Summary linked to this article.

\section{Data availability}

The authors declare that all data supporting the findings of this study are available upon request from the authors. The artifacts and faunal remains from the Fa-Hien Lena excavations are curated at the Department of Archeology, Government of Sri Lanka, under the site code BYP and the suffixes 10,11, and 12 (denoting the year of excavation). Some materials remained housed at the Max Planck Institute for the Science of Human History to be returned to the Department of Archeology, Government of Sri Lanka by the end of 2019. All of the data reported in the paper are presented in the main text or in the Supplementary Notes, Tables, and Figures.

Received: 19 September 2018 Accepted: 18 January 2019 Published online: 19 February 2019

\section{References}

1. Roberts, P. \& Stewart, B. A. Defining the 'generalist specialist' niche for Pleistocene Homo sapiens. Nat. Hum. Behav. 2, 542-550 (2018).

2. Finlayson, C. Neanderthals and Modern Humans: An Ecological and Evolutionary Perspective. (Cambridge Univ. Press, Cambridge, 2004)

3. Domínguez-Rodrigo, M. Is the "Savanna Hypothesis" a dead concept for explaining the emergence of the earliest hominins? Curr. Anthropol. 55, 59-81 (2014) 
4. Mellars, P. Going east: new genetic and archaeological perspectives on the modern human colonization of Eurasia. Science 313, 796-800 (2006).

5. Marean, C. The transition to foraging for dense and predictable resources and its impact on the evolution of modern humans. Philos. Trans. Roy. Soc. B 371, 1698 (2016).

6. Stiner, M. C. Thirty years on the "Broad Spectrum Revolution" and paleolithic demography. PNAS 98, 6993-6998 (2001).

7. Shea, J. J. Homo sapiens is as Homo sapiens was: behavioral variability versus "behavioral modernity" in Paleolithic archaeology. Curr. Anthropol. 52, 1-35 (2011).

8. Bird, M. I., Taylor, D. \& Hunt, C. Palaeoenvironments of insular Southeast Asia during the Last Glacial Period: a savanna corridor in Sundaland? Quat. Sci. Rev. 24, 2228-2242 (2005).

9. Boivin, N., Fuller, D. Q., Dennell, R., Allaby, R. \& Petraglia, M. D. Human Dispersal across Diverse Environments of Asia during the Upper Pleistocene. Quat. Int 300, 32-47 (2013).

10. Martin, P. S. \& Klein, R. G. Quaternary Extinctions: A Prehistoric Revolution (University of Arizona Press, Tucson, 1984).

11. Rule, S. et al. The aftermath of megafaunal extinction: ecosystem transformation in Pleistocene Australia. Science 355, 1483-1486 (2012)

12. Sandom, C., Faurby, S., Sandel, B. \& Svenning, J.-C. Global late quaternary megafauna extinctions linked to humans, not climate change. Philos. Trans. Roy. Soc. B 28, 20133254 (2014).

13. Barker, G. \& Farr, L. (eds) Archaeological Investigations in the Niah Caves, Sarawak (McDonald Institute for Archaeological Research, Cambridge, 2016).

14. Summerhayes, G. R. et al. Human adaptation and plant use in highland New Guinea 49,000 to 44,000 Years Ago. Science 330, 78-81 (2010).

15. Perera, N. et al. People of the ancient rainforest: Late Pleistocene foragers at the Batadomba-lena rockshelter. J. Hum. Evol. 61, 254-269 (2011).

16. Roberts, P. \& Petraglia, M. D. Pleistocene rainforests: barriers or attractive environments for early human foragers? World Archaeol. 47, 718-739 (2015).

17. Roberts, P. et al. Direct evidence for human reliance on rainforest resources in late Pleistocene Sri Lanka. Science 347, 1246-1249 (2015).

18. Deraniyagala, S. U. The Prehistory of Sri Lanka: An Ecological Perspective 2nd edn, (Department of Archaeological Survey, Colombo, 1992).

19. Wijeyapala, W. H. New Light on the Prehistory of Sri Lanka in the Context of Recent Investigations at Cave Sites (University of Peradeniya, Sri Lanka,1997).

20. Roberts, P., Boivin, N. \& Petraglia, M. D. The Sri Lankan 'Microlithic' tradition c. 38,000 to 3000 years ago: Tropical technologies and adaptations of Homo sapiens at the southern edge of Asia. J. World Prehist. 28, 69-112 (2015).

21. Perera, N. Prehistoric Sri Lanka: Late Pleistocene Rockshelters and an Open Air Site. (British Archaeological Reports International Series, Archaeopress, Oxford, 2010).

22. Perera, N., Roberts, P. \& Petraglia, M. Bone Technology from Late Pleistocene Caves and Rockshelters of Sri Lanka. In Osseous Projectile Weaponry. Towards an Understanding of Pleistocene Cultural Variability (ed. Langley, M. C.) 173-188 (Springer-Verlag, New York, 2016).

23. Kennedy, K. A. R. God-apes and Fossil Men. (University of Michigan Press, Ann Arbor, MI, 2000).

24. Dittus. W. P. J. Population dynamics of the toque monkey, Macaca sinica. In Socioecology and Psychology of Primates (ed. R. H. Tuttle) 125-151 (World Anthropology Series, The Hague, 1975).

25. Dittus, W. P. J. The socioecological basis for the conservation of the Toque monkey (Macaca sinica). In Primate Conservation (eds. Rainier III \& Bourne, G. H.) 237-265 (Academic Press, New York, 1977).

26. Stiner, M. C. The use of mortality patterns in archaeological studies of hominid predatory adaptations. J. Anthropol. Archaeol. 9, 305-351 (1990).

27. Cranbrook, E. \& Labang, D. Bearded pigs (Sus barbatus): tooth-wear and aging wild populations in Sarawak. Sarawak Museum. Journal 58, 163-182 (2003).

28. Piper, P. J. \& Rabett, R. J. Vertebrate fauna from the Niah Caves. In Archaeological Investigations in the Niah Caves, Sarawak (eds. Barker, G. \& Farr, L.) 401-438 (McDonald Institute for Archaeological Research, Cambridge, 2016).

29. Brandt, J. H. The Southeast Asian Negrito: further notes on the Negrito of South Thailand. J. Siam. Soc. 53, 27-43 (1965).

30. Kuchikura, Y. Efficiency and focus of blowpipe hunting among Semaq Beri hunter-gatherers of Peninsular Malaysia. Hum. Ecol. 16, 271-305 (1988).

31. Endicott, K. Batek. In The Cambridge Encyclopedia of Hunters and Gatherers (eds. Lee, R. B. \& Daly, R.) 298-306 (Cambridge University Press, Cambridge, 1999).

32. Fernandez-Jalvo, Y. \& Andrews, P. Atlas of Taphonomic Identifications (Springer, New York, 2016).

33. Rabett, R. J. Bone and tusk tools from the West Mouth and Lobang Hangus. In Archaeological Investigations in the Niah Caves, Sarawak (eds. Barker, G. \&
Farr, L.) 301-324 (McDonald Institute for Archaeological Research, Cambridge, 2016).

34. Peres, C. A. \& Dolman, P. Density compensation in Neotropical primate communities: Evidence from 56 hunted and non-hunted Amazonian forests of varying productivity. Oecologia 122, 175-189 (2000).

35. Fortier, J. The ethnography of south Asian foragers. Ann. Rev. Anthropol. 38, 99-114 (2009).

36. Mittermeier, R. A. Effects of hunting on rain forest primates. In Primate Conservation in the Tropical Rainforest (eds. Marsh, C. W. \& Mittermeier, R. A.) 109-146 (Liss, New York, 1987).

37. van Vliet, N., Milner-Gulland, E. J., Bousquet, F., Saqalli, M. \& Nasi, R. Effect of small-scale heterogeneity of prey and hunter distributions on the sustainability of bushmeat hunting. Conserv. Biol. 24, 1327-1337 (2010).

38. Erlandson, J. M. et al. The kelp highway hypothesis: marine ecology, the coastal migration theory, and the peopling of the Americas. J. Isl. Coast. Archaeol. 2, 161-174 (2007).

39. Roberts, P. et al. Fruits of the forest: Human stable isotope ecology and rainforest adaptations in Late Pleistocene and Holocene ( $\sim 36$ to $3 \mathrm{ka}$ ) Sri Lanka. J. Hum. Evol. 106, 102-118.

40. Gamble, C. Timewalkers: The Prehistory of Global Colonization. (Alan Sutton Press, Gloucester UK, 1993)

41. Gamble, C. Settling the Earth: The Archaeology of Deep Human History. (Cambridge University Press, Cambridge, 2013).

42. Hublin, J.-J. et al. New fossils from Jebel Irhoud, Morocco and the pan-African origin of Homo sapiens. Nature 546, 289-292 (2017).

43. Boivin, N. et al. Ecological consequences of human niche construction: examining long-term anthropogenic shaping of global species distributions. PNAS 113, 6388-6396 (2016).

44. Ashton, P. S. \& Gunatilleke, C. V. S. New light on the plant geography of Ceylon. I. historical plant geography. J. Biogeogr. 14, 249-285 (1987).

45. Erdelen, W. Forest ecosystems and nature conservation in Sri Lanka. Biol. Conserv. 43, 115-135 (1988).

46. Premathilake, R., Hunt, C. O., Perera, N. \& Wedage, O. Late Pleistocene humans used rice in Sri Lanka: phytolith investigation of the deposits at Fa Hien Rock Shelter. Global J. Human-Soc. Sci. D17, 19-30 (2017).

47. Premathilake, R., Hunt, C. O. Earliest Musa banana from the late Quaternary sequence at Fa Hien Rock Shelter in Sri Lanka. J. Quat. Sci. 33, 624-638 (2018).

48. OxCal version 4.3.2 (2017).

49. Bullock, P., Fedoroff, N., Jongerius, A., Stoops, G. \& Tursina, T. Handbook for Soil Thin Section Description (Waine Research, Wolverhampton, UK, 1985).

50. Stoops, G. Guidelines For Analysis and Description of Soil and Regolith Thin Sections (Soil Science Society of America Inc., Madison, USA, 2003).

51. Dobney, K. \& Reilly, K. A method for recording archaeological animal bones: the use of diagnostic zones. Circaea 5, 79-96 (1988).

52. von den Driesch, A. A Guide to the Measurement of Animal Bones from Archaeological Sites. (Harvard University Press, Cambridge, MA, 1976).

53. Wilson, D. E. \& Reeder, D. M. Mammal Species of the World (John Hopkins University Press, Baltimore, MD, 2005)

54. Thomas, D. H. Great basin hunting patterns: a quantitative method for treating faunal remains. Am. Antiq. 34, 392-401 (1969).

55. Grayson, D. K. Quantitative Zooarchaeology: Topics in the Analysis of Archaeological Faunas. (Studies in Archaeology, Academic Press, Cambridge, MA, 1984).

56. Behrensmeyer, A. K. Taphonomic and ecologic information from bone weathering. Paleobiology 4, 150-162 (1978).

57. Andrews, P. Experiments in taphonomy. J. Arch. Sci. 22, 147-153 (1995).

58. Shipman, P. \& Rose, J. Bone tools: an experimental approach. In Scanning Electron Microscopy in Archaeology (ed. Olsen, S. L.) 303-335 (British Archaeological Reports International Series, Archaeopress, Oxford, 1988).

59. Shipman, P., Foster, G. \& Schoeninger, M. Burnt bones and teeth: an experimental study of color, morphology, crystal structure and shrinkage. J. Arch. Sci. 11, 307-325 (1984).

60. Johnson, E. Human modified bones from early southern Plains Sites. In Bone Modification (eds. Bonnichsen, R. \& Sorg, M.) 431-471 (Center for the Study of First Americans, Orono, ME, 1989).

61. Brain, C. K. The Hunters or the Hunted? An Introduction to African Cave Taphonomy. (Chicago University Press, Chicago, IL, 1981).

62. Cain, C. R. Using burned animal bone to look at middle stone age occupation and behavior. J. Arch. Sci. 32, 873-884 (2005).

63. Bar-Oz, G., Belfer-Cohen, A., Meshveliani, T., Djakeli, N. \& Bar-Yosef, O. Taphonomy and zooarchaeology of the Upper Palaeolithic cave of Dzudzuana, Republic of Georgia. Int J. Osteoarch 18, 131-151 (2008).

64. Klein, R. G. \& Cruz-Uribe, K. The Analysis of Animal Bones from Archeological Sites. (Chicago University Press, Chicago, IL, 1984).

65. Lyman, R. L. Vertebrate Taphonomy. (Cambridge Manuals in Archaeology, Cambridge University Press, Cambridge, UK, 1994). 
66. Bunn, H. T. Comparative analysis of modern bone assemblages from a San hunter-gatherer camp in the Kalahari Desert camp, Botswana, and from a spotted hyena den near Nairobi, Kenya. (British Archaeological Reports International Series, Archaeopress, Oxford, 1983).

67. Marean, C. W., Dominguez-Rodrigo, M. \& Pickering, T. R. Skeletal element equifinality in zooarchaeology begins with method: the evolution and status of the "shaft critique". J. Taphon. 2, 69-98 (2004).

68. Pelegrin, J., Karlin, C. \& Bodu, P. Chaînes opératoires: un outil pour le préhistorien. Technol. préhistorique 25, 55-62 (1988).

69. Lemonnier, P. The study of material culture today: toward an anthropology of technical systems. J. Anthropol. Archaeol. 5, 147-186 (1986).

70. Inizan, M.-L., Roche, H. \& Tixier, J. Technology of Knapped Stone. Prehistoire de la pierre taillée, Vol. 3 (CREP, Meudon, 1992).

71. Backwell, L., d'Errico, F. \& Wadley, L. Middle stone age bone tools from Howiesons Poort layers, Sibudu Cave, South Africa. J. Arch. Sci. 35, 1566-1580 (2008).

72. Blasco, R., Rosell, J., Fernández Peris, J., Caceres, I. \& María Vergès, J. A new element of trampling: an experimental application on the Level XII faunal record of Bloomer Cave (Valencia, Spain). J. Arch. Sci. 35, 1605-1618 (2008).

73. Bradfield, J. \& Brand, T. Results of utilitarian and accidental breakage experiments on bone points. Archaeol. Anthropol. Sci. 7, 27-38 (2015).

74. Buc, N. Experimental series and use-wear in bone tools. J. Arch. Sci. 38, 546-557 (2011).

75. Buc, N. \& Loponte, D. Bone tool types and micro wear patterns: Some examples from the Pampa Region, South America. In Bones as Tools: Current Methods and Interpretations in Worked Bone Studies (eds. Gates St-Pierre, C., Walker, R. B.) 143-147 (British Archaeological Reports International Series, Archaeopress, Oxford, 2007).

76. Gates St-Pierre, C. 2007. Bone awls of the St. Lawrence Iroquoians: A micro wear analysis. In Bones as Tools: Current Methods and Interpretations in Worked Bone Studies (eds. Gates St-Pierre, C., Walker, R. B.) 107-118 (British Archaeological Reports International Series, Archaeopress, Oxford, 2007).

77. Langley, M. C., O'Connor, S. \& Aplin, K. A>46,000-year-old macropod bone implement from Carpenter's Gap 1: Challenging past perspectives of Pleistocene Australia. Quat. Sci. Rev. 154, 199-213 (2016).

78. Legrand, A. \& Sidéra, I. Methods, means, and results when studying European bone industries. In Bones as Tools: Current Methods and Interpretations in Worked Bone Studies (eds. Gates St-Pierre, C., Walker, R. B.) 67-79 (British Archaeological Reports International Series, Archaeopress, Oxford, 2007).

\section{Acknowledgements}

We thank Rev. Chandima Thero, Rev. Anandasagara Thero, and the other monks at the Fa-Hien Lena Cave temple. We would also like to thank Prof. S. Disanayaka, Prof. P.B.
Mandawala, Mr. S.A.T.G. Priyantha, Mr L.V.A. De. Mel, and other members at the excavation Branch of the Department of Archeology, Sri Lanka. This research is supported by the research council of the University of Sri Jayewardenepura (RC-USJ) and the Max Planck Institute for the Science of Human History.

\section{Author contributions}

O.W., N.A., M.D.P., and P.R. designed the research; O.W., N.A., M.C.L., K.D., J.B., A.C., S.D., N.K., I.S., A.P., N.B., M.D.P., and P.R. collected the data; O.W., N.A., M.C.L., K.D., J.B., A.C., S.D., N.K., I.S., A.P., N.P., N.B., M.D.P., and P.R. analyzed the data; O.W., N.A., M.C.L., K.D., J.B., A.C., S.D., N.K., I.S., A.P., N.P., N.B., M.D.P., and P.R. wrote the paper.

\section{Additional information}

Supplementary Information accompanies this paper at https://doi.org/10.1038/s41467019-08623-1.

Competing interests: The authors declare no competing interests.

Reprints and permission information is available online at http://npg.nature.com/ reprintsandpermissions/

Journal peer review information: Nature Communications thanks Melinda A. Zeder and the other anonymous reviewer for their contribution to the peer review of this work. Peer reviewer reports are available.

Publisher's note: Springer Nature remains neutral with regard to jurisdictional claims in published maps and institutional affiliations.

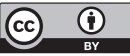

Open Access This article is licensed under a Creative Commons Attribution 4.0 International License, which permits use, sharing, adaptation, distribution and reproduction in any medium or format, as long as you give appropriate credit to the original author(s) and the source, provide a link to the Creative Commons license, and indicate if changes were made. The images or other third party material in this article are included in the article's Creative Commons license, unless indicated otherwise in a credit line to the material. If material is not included in the article's Creative Commons license and your intended use is not permitted by statutory regulation or exceeds the permitted use, you will need to obtain permission directly from the copyright holder. To view a copy of this license, visit http://creativecommons.org/ licenses/by/4.0/.

(C) The Author(s) 2019 